Article

\title{
Students' Perception towards E-Learning during COVID-19 Pandemic in India: An Empirical Study
}

\author{
Mohammed Arshad Khan ${ }^{1, *(\mathbb{D}}$, Vivek ${ }^{2}\left(\mathbb{D}\right.$, Mohammed Kamalun Nabi ${ }^{2}$, Maysoon Khojah ${ }^{1}$ \\ and Muhammad Tahir ${ }^{3}$ \\ 1 Department of Accountancy, College of Administrative and Financial Sciences, Saudi Electronic University, \\ Riyadh 11673, Saudi Arabia; m.khoja@seu.edu.sa \\ 2 Department of Commerce and Business Studies, Jamia Millia Islamia, New Delhi 110025, India; \\ vs22.vivek@gmail.com (V.); mnabi@jmi.ac.in (M.K.N.) \\ 3 College of Computing and Informatics, Saudi Electronic University, Riyadh 11673, Saudi Arabia; \\ m.tahir@seu.edu.sa \\ * Correspondence: m.akhan@seu.edu.sa
}

Citation: Khan, M.A.; Vivek; Nabi, M.K.; Khojah, M.; Tahir, M. Students' Perception towards E-Learning during COVID-19 Pandemic in India: An Empirical Study. Sustainability 2021, 13, 57. https://dx.doi.org/10.3390/ su13010057

Received: 8 December 2020

Accepted: 19 December 2020

Published: 23 December 2020

Publisher's Note: MDPI stays neutral with regard to jurisdictional claims in published maps and institutional affiliations.

Copyright: () 2020 by the authors. Licensee MDPI, Basel, Switzerland. This article is an open access article distributed under the terms and conditions of the Creative Commons Attribution (CC BY) license (https: / / creativecommons.org/ licenses/by/4.0/).

\begin{abstract}
The educational system across the world has immensely been affected due to outbreak of COVID-19; it forced the shut down of educational institutions, which adversely affected student fraternity across the globe. Due to its contagious nature, COVID-19 demanded containment and enforced isolation that tremendously affected personal interaction of teachers and students. In the absence of traditional classroom teaching and one-to-one interaction, computer-based learning has emerged as closest substitute for off-line teaching. Against such a backdrop, it is pertinent to examine the students' perception and readiness about online-learning system adopted at the university level during the ongoing COVID-19 pandemic. For the present study, the quantitative approach has been adopted and responses from 184 university students of National Capital Territory (NCT) of Delhi, India namely Delhi University, Jamia Millia Islamia (Central University) and Guru Gobind Singh Indraprastha University are collected through online questionnaire. This research study was conducted during June-August 2020. The findings of the study reveal students' positive perception towards e-learning and thus acceptance of this new learning system. It has also empirically demonstrated the significance of e-learning in the time of COVID-19 crisis. In fact, e-learning has emerged as a new way of enhancing the learning process where social media may further improve the learning output. The findings of the study will facilitate educational institutions and policy makers to take this online-learning process to the next level in a better way.
\end{abstract}

Keywords: students' perception; E-learning; COVID-19; traditional classroom learning

\section{Introduction}

The effect of information technology on human life is immense and its role in education too cannot be subsided. In the current scenario of COVID 19 pandemic, the contribution of information technology has gained momentum due to closure of educational institutions that raises challenges for students' learning. During this quarantine time information technology is serving the solution for the ongoing learning process through innovative and learning management systems [1,2]. It has provided opportunity for educators to implement IT solutions for teaching as well as evaluation for the completion of course work of students. The efforts of stakeholders namely teachers, students and institutional administrators are on for the optimal use of the technology and efficient learning process [3]. The ultimate goal is to minimize the learning gap that arouse due to lockdown.

Educational institutions and students across the world have accepted and appreciated the online platform of learning. The reasons of this acceptability are ease of use, learning flexibility and controllable environment. However, despite its multiple advantages there are quite a few limitations of e-learning such as social isolation, face to face interaction 
between teacher and student, connectivity issues, etc. [4]. E-learning has never been adopted and accepted as real learning or the formal mode of education before this ongoing pandemic that compelled to resort to electronic learning solution by world over [5]. Now, at the hour of pandemic crisis, most of the educational institutions are exploring and approaching towards e-learning to make it easy for students to work out at new normal. Also, various e-teaching software are being explored by teachers or educators to bring maximum possible ease for their students [6].

As a matter of fact, as this e-learning wave is a recent development, teachers as well as students are in the process of adapting this new teaching and learning methodology. At this prevailing situation of virtual teaching and setting of new normal of teaching-learning methodology, it becomes all more important to get to know the opinion of learners and to explore learners' inclination towards this novel teaching methodology, such as their degree of adaptation and amendment if any they would like to suggest for the same or want to reject it altogether [7]. Against such a backdrop, this study aims to examine the perception of e-learning during COVID-19 lockdown period.

\section{Literature Review}

In the recent time, the research on exploring students' perception and their expectation from e-learning has been on surge [8,9]. "National Center for Education Statistics" has reported the growing requirement of e-learning due to its increasing acceptance recently. Several studies indicate that most of the students enrolled in online courses are satisfied with the mode of learning. However, studies also reveal that perceptions of learners are affected by a host of factors [10-12].

Factors such as age, gender, prior knowledge of computer literacy and learning styles of individual are the vital predictors of technology acceptance by students. There exists ample literature which discusses the theories of "technology acceptance" to study students' perception [13].

Country-wise research in the area as listed are contributed by Australia [14,15], United States [16,17] and in the United Kingdom [18]. These studies confirm that a majority of learners have their own internet enabled devices such as personal computers and mobile phones. They are using these digital devices for communication over formal and informal platforms of networking such as emails, blogging, etc. This study is based on the students' expertise, expectation and perception of e-learning. Relevant literature is consulted to find the possible answers particularly in the area of users' perception towards innovation. "Theory of diffusion of innovations" $[19,20]$ is so far is one of the most relevant theories used for the study of technology adoption in higher education. Roger has defined users' perception of innovation immensely affects its adoption by them. The perception of relative advantage, the degree to which the innovation is perceived as better one than the compared product, compatibility, consistency with current value set up, past behaviour and experience of innovation recipients, the extent of complexities associated in understanding and making use of innovation.

As per "Technology Acceptance Model", two most important determining factors for technology acceptance are perceived usefulness and perceived ease of use [21].

The study investigated the relationships among course structure/organization, learner interaction, student engagement, and instructor presence on student satisfaction and perceived learning in the online learning environments. This study indicated a significant relationship between course structure and perceived student learning. Furthermore, the data indicated that student interaction does not have a statistically significant impact on student satisfaction yet instructor presence does have a statistically significant impact on perceived student learning. The data, however, indicated that learner interaction does significantly impact perceived student learning. The data also indicated that instructor presence does influence student satisfaction. The mediated variable, student engagement, partially mediated the impact that instructor presence has on student satisfaction. Furthermore, student engagement fully mediated the impact of both instructor presence and learner interaction 
on perceived student learning [22]. Online learning is still new, and it is continuously evolving by the rapidly changing technologies. More efforts are required by all online educators to integrate pedagogy with technologies in order to enhance student learning. In nutshell, online discourse as a communication activity could be very beneficial in current online learning environment to the students or learners, by providing a space for information exchange and to generate deeper thinking, but only if educators understand how it would work and how students learn in the online environment [23]. This survey-based research study examined the perception of students on various engagement strategies used in online courses. Learner-to-instructor engagement strategies seemed to be most valued among the three categories of student engagement. Icebreaker/introduction discussions and working collaboratively by using online communication tools were rated the most beneficial engagement strategies in the learner-to-learner category, whereas sending regular announcements or email reminders and providing grading rubrics for all assignments were rated most beneficial in learner-to-instructor category. Thus, we can conclude that student engagement increases student satisfaction, enhances student motivation to learn, reduces the sense of isolation, and improves student performance in the online learning environment. The results of the study have implications for online instructors, instructional designers, and administrators who wish to enhance engagement in the online courses [24]. This research study was conducted to investigate the perception of academic stress experienced by students during current online education and coping strategies using emotional intelligence adopted by them. The findings of the study indicated that significant differences were observed between the fear of academic failure and online and home environment among male and female students. Many of them have started diverting themselves to various creative activities and taking up online courses that are helping them to learn new technical skills. Thus, by using emotional intelligence and distancing from boredom and depressive thoughts, students were trying to cope with negative effects arising from the current pandemic situation in this new environment of online education [25].

The Massive Open Online Courses (MOOC) has exerted a significant influence on adult learning. The current study tries to investigate the MOOCs' effect on higher education systems. This research found the majority of university faculty think that MOOCs has a direct impact on improving educational outcomes. Furthermore, the research data support that MOOCs has a direct impact on developing students' learning skills. Thus, we can conclude that MOOC is a suitable platform to train entrepreneurs because it provides tools to enable students' collaborative mastering as properly as enhancing individuals' affective key entrepreneurial factors together with such possibility reputation and aid acquisition [26,27]. The present study analysed the satisfaction level of the participants from the MOOC run by Swayam, Coursera, FutureLearn and Edx. The satisfaction from the MOOCs has been studied on four parameters i.e., course delivery, course content, course assessment, and course support. The qualitative results highlighted that the participants have gained knowledge from the course and 65\% of them preferred Swayam and Coursera MOOC portals. The overall findings revealed that participants were more satisfied than dissatisfied from the MOOC. Thus, MOOC providers should focus more on building great course content, ensuring timely and flawless delivery of the lectures along with appropriate course assessment, covering the correct information from the course content. Hence, the satisfaction of participants can be achieved and they can be encouraged to further enroll in other courses along with completing the current course [28].

\subsection{Research Gap}

The review of literature reveals that most of the studies are undertaken to identify students' perception and attitude towards e-learning and studies related to students' perception of e-learning at the time of COVID-19 pandemic are found to be few and far between. 


\subsection{Objectives of the Study}

1. To cognize the importance of e-learning during the phase of ongoing pandemic.

2. To study the benefits of online mode of learning from the perspective of students.

3. To analyse the students' perceptions of e-learning during Covid-19 lockdown period.

\section{Methodology}

This study is quantitative as well as descriptive in nature and used both primary and secondary data for the analysis. A modified questionnaire has been used to collect data from 184 students enrolled in various universities of NCT of Delhi, India, namely Delhi University, Jamia Millia Islamia (Central University) and Guru Gobind Singh Indraprastha University. The respondents of the survey are the students who are actively using e-learning platforms for their regular course during COVID -19 lockdown. The survey was conducted in the National Capital Territory (NCT) of Delhi during June to August 2020.

The questionnaire consisted of two sections. Section A collects personal information of students. Section B of the Questionnaire gauges the perception and attitude of students in regard to the effectiveness of e-learning during COVID-19. The questionnaire is finalized after minor changes required after pilot survey for the assessment of feasibility of the survey. For the purpose of validation and analysis of the collected data from the sample respondents, appropriate statistical tools and techniques have been used by the researcher. Cronbach's alpha technique was considered in the study for measuring the internal consistency between the manifest variables or reliability of the latent constructs that have been used in the study. To examine that whether all the measured variables are explicitly explaining their respective latent construct or not, Confirmatory Factor Analysis (CFA) technique was applied in the study through AMOS (version 24) software. To analyse the benefits of online mode of learning and to study the perception of students towards e-learning during this ongoing pandemic as well, SPSS (version 25) software was used by the researcher.

\section{Results and Findings}

For the collection of primary data, the questionnaire was randomly distributed through online form - Google doc. Social networking sites have been a significant source of reaching out to students enrolled in different universities. 184 valid responses are recorded that qualify for data analysis. SPSS software is used for the analysis of data collected. The demographic profile of the students, the device which the students use for the access of online-learning, duration of using the computer, and students' perception and attitude in regard to e-learning are presented below.

\subsection{Profile of the Sample Respondents}

This section presents some basic information of the university students. Table 1 shows the outputs of the questions related to gender, age group, course and level of education. All the data presented here is compiled form primary data. 
Table 1. Personal Information of Sample Respondents $(N=184)$.

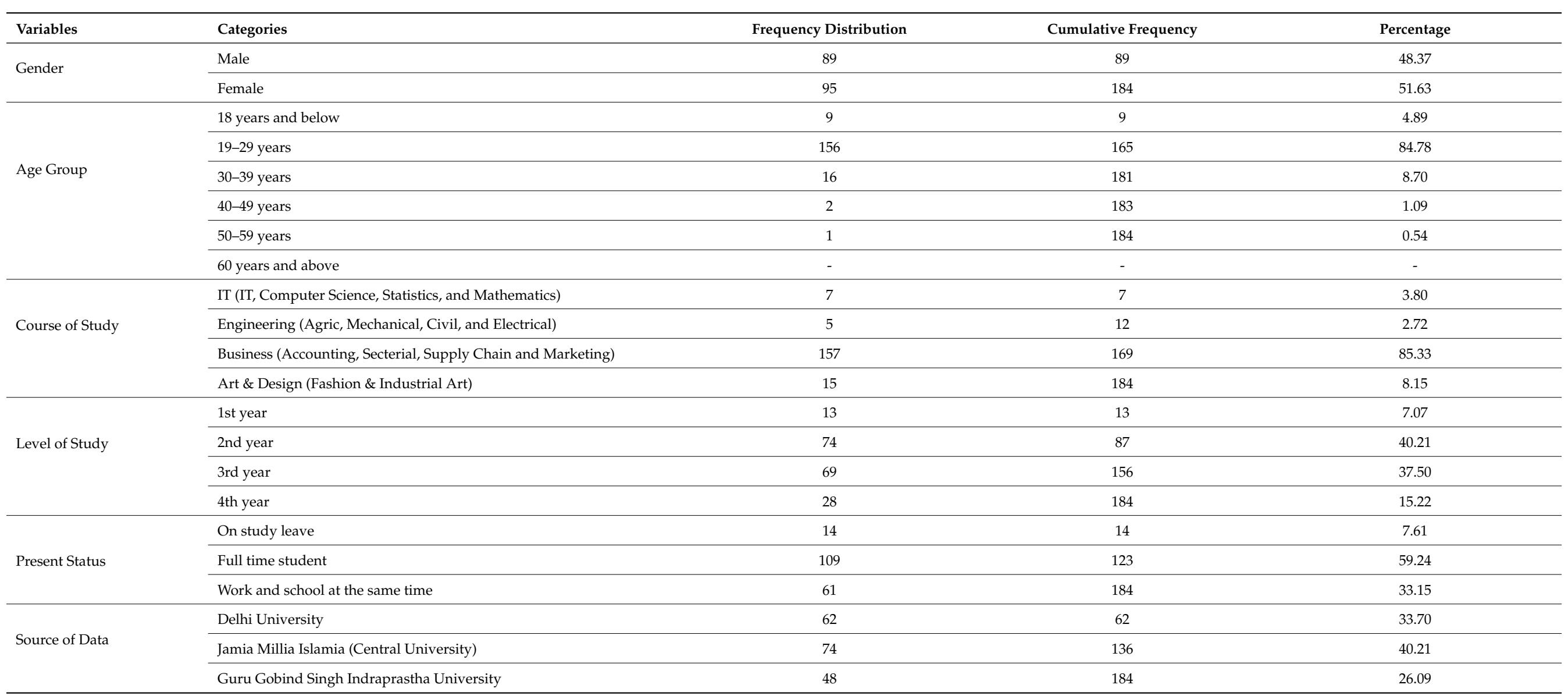


Table 1 depicts the personal information of the respondents classified on the basis of their gender, age group, level of education, academic year, and present status of the sample respondents. It is revealed from the aforesaid Table that majority of the sample respondents $(51.63 \%)$ were females whereas $48.37 \%$ were males. $84.78 \%$ of the respondents belong to the age group 19-29 years, $8.70 \%$ are in the age group $30-39$ years and $4.89 \%$ of students are below 18 years of age. None of the respondents belongs to the age group of 60 years and above, while only $1.09 \%$ falls within the age group of $40-49$ years and $0.54 \%$ of the respondents were within 50-59 years. Respondents belonging to 19-29 age group represent the voice of the youth. Students are justifiably distributed as per their academic year of study. As presented in Table 1, 7.07\% respondents are in first year, $40.21 \%$ are in second year, $37.50 \%$ are in third year, and $15.22 \%$ are in fourth year, respectively. $59.24 \%$ of the total responses have been recorded from full time students, $7.61 \%$ from students who are on study leave, $33.15 \%$ are working as well as pursuing their studies. $85.33 \%$ of the total respondents are from business management course, $8.15 \%$ from the course of Art/Design, $3.80 \%$ from IT and the rest $2.72 \%$ are from Engineering stream. Therefore, fairly various groups of students have been included in the study to have their views.

As far as the sources of sample data is concerned, the students enrolled in the numerous universities located in Delhi such as Delhi University, Jamia Millia Islamia (Central University) and Guru Gobind Singh Indraprastha University were considered in the study. Majority of the students (40.21\%) belong to the Jamia Millia Islamia (Central University), followed by Delhi University students (33.70\%) and the remaining $26.09 \%$ of the students were studying in Guru Gobind Singh Indraprastha University.

\subsection{Reliability of the Latent Constructs}

Testing the reliability is an important step, as it checks the internal consistency and inspects the properties of measuring scale [29]. This study used Cronbach's alpha as a measure of reliability, which is a commonly applied measure in Likert scale survey questions. Table 2 gives the value of Cronbach's alpha for each of the construct considered separately. The information presented here is prepared by the Researchers through SPSS Output.

Table 2. Reliability of the Constructs.

\begin{tabular}{lcc}
\hline Latent Constructs & Cronbach's Alpha & No. of Items \\
\hline Benefits of E-learning & 0.922 & 10 \\
\hline Students' Perceptions of E-learning & 0.957 & 14 \\
\hline
\end{tabular}

The reliability value of Cronbach's alpha between \pm 0.41 and \pm 0.70 qualifies for moderate reliability of the scale measured, while greater value than \pm 0.70 shows high internal consistency [30]. The Cronbach's alpha [31] values between 0.70 to 0.90 exceed the level of acceptability. As depicted in Table 2, Cronbach's alpha value is little over 0.90 and hence holds good internal consistency allowing for further analysis.

\subsection{The Benefits of E-Learning}

The study investigates the benefits of e-learning for students enrolled at different educational institutions. To measure the degree of benefits availed from e-learning, questions listed in Table 3 are asked on five-point Likert Scale-based statements ranging from "Strongly Disagree" to "Strongly Agree".

"Strongly Agree" and "Agree" are clubbed together to form one positive response of "Agree". The same procedure is applied in case of "Strongly Disagree" and "Disagree" and they are combined to get one response from the sample respondents which is "Disagree". "Neutral" was left as it is. The results are shown in Table 3. The information in Table 3 is prepared by the Researchers through SPSS Output. 
Table 3. Benefits of E-Learning $(N=184)$.

\begin{tabular}{|c|c|c|c|c|c|c|c|c|}
\hline Code & Variables & SD(1) & $D(2)$ & Total $(1+2)$ & $\mathbf{N}(3)$ & $\mathrm{A}(4)$ & SA(5) & Total $(4+5)$ \\
\hline BEL1 & Flexibility in Time and Space & $6 \%$ & $8.2 \%$ & $14.2 \%$ & $24.5 \%$ & $39.1 \%$ & $22.2 \%$ & $61.3 \%$ \\
\hline BEL2 & Ease and quick share of educational material & $5.4 \%$ & $4.9 \%$ & $10.3 \%$ & $16.3 \%$ & $43.5 \%$ & $29.9 \%$ & $73.4 \%$ \\
\hline BEL3 & Improved collaboration and interactivity among students & $9.8 \%$ & $29.3 \%$ & $39.1 \%$ & $27.7 \%$ & $21.7 \%$ & $11.5 \%$ & $33.2 \%$ \\
\hline BEL4 & Access to higher education for all applicants & $8.7 \%$ & $19 \%$ & $27.7 \%$ & $26.1 \%$ & $27.7 \%$ & $18.5 \%$ & $46.2 \%$ \\
\hline BEL5 & Possibility of working with e-learning & $6.5 \%$ & $10.9 \%$ & $17.4 \%$ & $23.4 \%$ & $37 \%$ & $22.2 \%$ & $59.2 \%$ \\
\hline BEL6 & Accommodates different types of learning styles & $4.9 \%$ & $10.9 \%$ & $15.8 \%$ & $28.8 \%$ & $41.8 \%$ & $13.6 \%$ & $55.4 \%$ \\
\hline BEL7 & Quick feedback & $4.8 \%$ & $11.4 \%$ & $16.2 \%$ & $28.3 \%$ & $34.8 \%$ & $20.7 \%$ & $55.5 \%$ \\
\hline BEL8 & Wide and diverse interactions & $5.4 \%$ & $14.7 \%$ & $20.1 \%$ & $26.1 \%$ & $39.1 \%$ & $14.7 \%$ & $53.8 \%$ \\
\hline BEL9 & Access study resources effectively & $7.1 \%$ & $10.3 \%$ & $17.4 \%$ & $21.2 \%$ & $38.6 \%$ & $22.8 \%$ & $61.4 \%$ \\
\hline BEL10 & Updated learning material & $4.3 \%$ & $6.5 \%$ & $10.8 \%$ & $20.7 \%$ & $43.5 \%$ & $25 \%$ & $68.5 \%$ \\
\hline
\end{tabular}

The analysis of Table 3 depicts that the highest response rate was $73.4 \%$ with regard to "Ease and Quick Share of Educational Material". It reveals that through the medium of e-learning, instructor and learner can easily and quickly share the educational material with each other, while only $10.3 \%$ of the sample respondents opined that e-learning system is not helpful in sharing the-learning material, pedagogical material, instructional material etc. The second highest positive response rate was $68.5 \%$ with regard to "Updated Learning Material".

However, $10.8 \%$ of the students are of the opinion that updated material in webbased learning is not supportive in designing the new curriculum and teaching strategies, while $17.4 \%$ of the students have opined that they are unable to get the study resources through web-based learning system. In terms of "Access Study Resources Effectively" the results show that $61.4 \%$ of students have indicated this factor as a positive one. Thus, it can be concluded that with the help of e-learning system students can get easily the various study resources. It is needless to mention here is that as per international recognition, it is desirable to have updated learning course material at online platform. In case of variable "Flexibility in Time and Space" the positive response rate was $61.3 \%$. This shows that for majority of students, e-learning has emerged as a convenient option when matter comes to flexibility of time and geographical space. Flexible-learning can be understood as learning mode where teaching-learning are independent of any geographical location, time or pace.

The positive rate of response received on the factor - "Possibility of Working with E-learning" is $59.2 \%$. This shows majority of the students have capability to leverage the elearning platform as they find it user friendly. The efficient learning management system is the one that has various tools embedded in it to make it accommodative and manageable for e-learning course $[32,33]$. This implies that not all e-learning platforms are not open source due to limited embedded applications and security reasons. Also, from Table 3, variable - "quick feedback" has received $55.5 \%$ of positive response. Particularly in the context of e-learning quick feedback is important as timely and quick responses make students more involved in discussion fora and hence catalyse the e-learning process. The variable "accommodates different types of learning style"; received $55.4 \%$ of positive responses which indicates that majority of students appreciate the accommodative nature of e-learning platform for various learning styles. This finding aligns itself with the past studies that affirms possibility of e-learning to accommodate different learning contents [34].

For the variable "wide and diverse interactions", $53.8 \%$ positive responses are received. This indicates that over half of the total respondents are comfortable with the-learning at online platform; though they are away with physical interaction. Also, they are well 
aware of the fact that cultural diversification groups are meeting online and interacting during the-learning process. The variable "Access to Higher Education for all Applicants" received $46.2 \%$ of positive responses which indicates that a little less than half of the respondents believe in the increment of the opportunities for students to get enrolled in higher education system through online mode. Because of overcoming the limitation of geographical proximity, e-learning has been as great enabler of access to higher education and hence providing more opportunities to learners [35,36]. E-learning enables working people to get enrolled and study along with their job. E-learning has been responsible for much of such enrolments and increasing the literacy rate of the citizens [37,38].

The least positive response rate was $33.2 \%$ with regard to "Improved Collaboration and Interactivity among Students". Collaboration is much important in contemporary scenario and has been a relevant subject for researchers due to its inherent nature of knowledge sharing. The responses so received however are mixed with the degree of agreement, disagreement and being neutral. It indicates that there is much need to understand the importance of collaboration for the sake of knowledge sharing.

\subsection{Students' Perceptions of E-Learning}

Confirmatory Factor Analysis (CFA) is used for the verification whether all the measured variables are clearly explaining their respective latent construct or not. To analyze the students' perceptions of e-learning system, several sub-constructs with their respective measured variables have been included in the latent construct namely "Perception of Students towards E-learning" [39]. The CFA measurement model for the same latent construct depicting how each measure variable is correlated with its assumed theoretical construct is presented in Figure 1 that is prepared by the Researchers through AMOS Software.

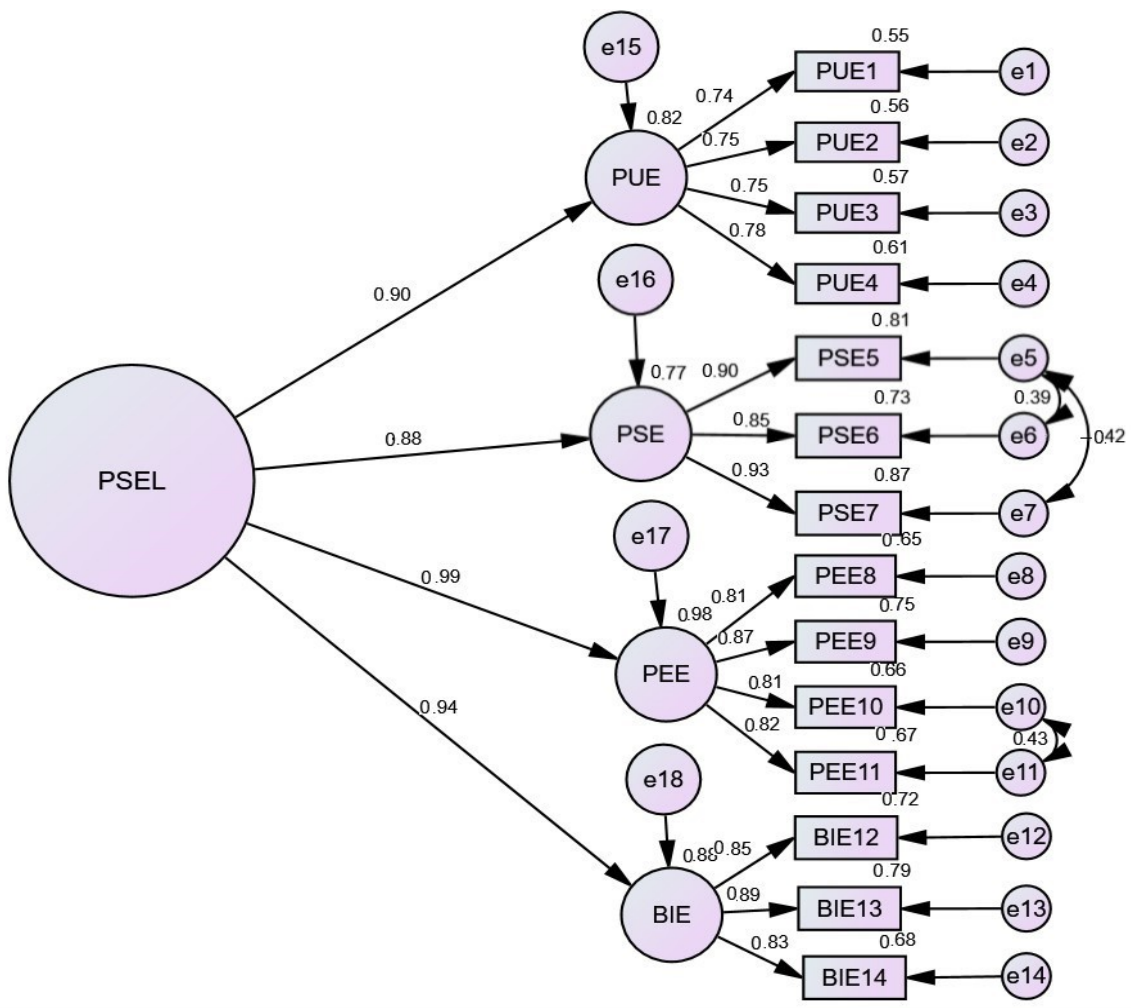

Figure 1. CFA Measurement Model for "Students' Perceptions of E-learning".

Figure 1 discerns that the major latent variable i.e., "Perception of Students towards E-learning (PSEL)" is measured by its four sub-constructs namely Perceived Usefulness of E-learning (PUE), Perceived Self-Efficacy of Using E-learning (PSE), Perceived Ease of Use of E-learning (PEE), and Behavioural Intention of Using E-learning (BIE). The first sub-construct coded as PUE is measured through four statements (PUE1, PUE2, PUE3, 
and PUE4) which is represented by rectangles as the convention followed for observed variables. The second sub-construct namely "Perceived Self-Efficacy of Using E-learning" is measured through three statements coded as PSE5, PSE6, and PSE7. Similarly, the variable namely "Perceived Ease of Use of E-learning" and "Behavioural Intention of Using Elearning" are measured by four statements coded as PEE8, PEE9, PEE10, PEE11 and BIE12, BIE13 and BIE14 respectively. The small circles with arrows show residual terms, which represents how much variation in the endogenous variable is unexplained by the exogenous variable. Factor loading for given item is mentioned in the proximity of pointing arrow drawn and multiple correlations are mentioned above each response item of manifest variable. To solve the problem of redundancy between items and improving the results of model fit indices, three redundant items (i.e., e $5 \leftrightarrow \mathrm{e} 6$, e $5 \leftrightarrow \mathrm{e} 7$, and e10 $\leftrightarrow \mathrm{e} 11$ ) were constrained as "free parameter" in the measurement model. Tables 4-6 depict the analysis summary of the aforesaid model provided by AMOS 24 .

Table 4 shows that Chi-square $p$-value is 0.135 (more than $5 \%$ ) and CMIN/DF value is 2.041 (less than 3) which reveals that data is suitable for the model fit. The model also generated other indices of goodness i.e., $\mathrm{GFI}=0.910, \mathrm{AGFI}=0.849, \mathrm{CFI}=0.967, \mathrm{NFI}=0.937$ all of which exceed their threshold limits depicting that this is a well-fitted model and two indices of badness i.e., RMSEA $=0.020$ (less than 0.10) and SRMR $=0.022$ (less than 0.09) reveal that the data fits the model well because lower RMSEA and SRMR value indicates better fit. Thus, it reveals that the aforesaid CFA measurement model is a well-fitted model.

Table 5 reveals that all the manifest variables related to their respective latent construct depicted in Figure 1 are statistically significant since their $p$-values are less than $5 \%$ significance level. It further explains that convergent validity of the above discussed CFA measurement model is also achieved since each measured variable or manifest variable or observed variable is strongly correlated with its assumed theoretical construct with the standardized regression weights of more than 0.4 [40].

Table 4. CFA Model-Fit Summary.

\begin{tabular}{|c|c|c|c|}
\hline Name of Category & $\begin{array}{l}\text { Model } \\
\text { Fit Indices }\end{array}$ & Threshold Limits & $\begin{array}{l}\text { Values } \\
\text { Attained }\end{array}$ \\
\hline \multirow{4}{*}{ Absolute Fit Indices } & $x^{2}$ & $p$-value $>0.05$ & 0.134 \\
\hline & RMSEA & $\begin{array}{l}<0.05 \text { good fit; } 0.05-0.10 \text { mediocre fit; } \\
\text { and if }>0.10 \text { bad fit }\end{array}$ & 0.020 \\
\hline & SRMR & $<0.09$ & 0.022 \\
\hline & GFI & $>0.90$ & 0.910 \\
\hline \multirow{4}{*}{ Incremental Fit Indices } & AGFI & $>0.80$ & 0.849 \\
\hline & CFI & $\begin{array}{l}>0.95 \text { great; }>0.90 \text { traditional; and if } \\
>0.80 \text { sometimes permissible }\end{array}$ & 0.967 \\
\hline & TLI & $>0.90$ & 0.957 \\
\hline & NFI & $>0.90$ & 0.937 \\
\hline Parsimonious Fit & $\mathrm{CMIN} / \mathrm{DF}$ & $<3$ good; and if $<5$ sometimes permissible & 2.041 \\
\hline
\end{tabular}


Table 5. Path Analysis.

\begin{tabular}{lcccc}
\hline Path & $\begin{array}{c}\text { Std. } \\
\text { Regression Coefficients }\end{array}$ & Variance Explained & Critical Ratio & $p$-Value \\
\hline PSEL $\rightarrow$ PUE & 0.904 & 0.817 & 9.875 & $<0.001$ \\
\hline PSEL $\rightarrow$ PSE & 0.878 & 0.771 & 11.959 & $<0.001$ \\
\hline PSEL $\rightarrow$ PEE & 0.991 & 0.982 & 10.321 & $<0.001$ \\
\hline PSEL $\rightarrow$ BIE & 0.937 & 0.878 & 12.091 & $<0.001$ \\
\hline PUE $\rightarrow$ PUE1 & 0.739 & 0.546 & 9.479 & $<0.001$ \\
\hline PUE $\rightarrow$ PUE2 & 0.749 & 0.561 & 9.860 & $<0.001$ \\
\hline PUE $\rightarrow$ PUE3 & 0.752 & 0.565 & 9.893 & $<0.001$ \\
\hline PUE $\rightarrow$ PUE4 & 0.782 & 0.612 & 10.309 & $<0.001$ \\
\hline PSE $\rightarrow$ PSE1 & 0.902 & 0.813 & 10.572 & $<0.001$ \\
\hline PSE $\rightarrow$ PSE2 & 0.852 & 0.727 & 18.679 & $<0.001$ \\
\hline PSE $\rightarrow$ PSE3 & 0.934 & 0.872 & 15.708 & $<0.001$ \\
\hline PEE $\rightarrow$ PEE1 & 0.809 & 0.655 & 12.245 & $<0.001$ \\
\hline PEE $\rightarrow$ PEE2 & 0.869 & 0.755 & 13.989 & $<0.001$ \\
\hline $\mathrm{PEE} \rightarrow$ PEE3 & 0.810 & 0.656 & 12.620 & $<0.001$ \\
\hline $\mathrm{PEE} \rightarrow$ PEE4 & 0.819 & 0.670 & 12.821 & $<0.001$ \\
\hline $\mathrm{BIE} \rightarrow$ BIE1 & 0.848 & 0.719 & 13.338 & $<0.001$ \\
\hline $\mathrm{BIE} \rightarrow$ BIE2 & 0.889 & 0.790 & 15.527 & $<0.001$ \\
\hline $\mathrm{BIE} \rightarrow$ BIE3 & 0.825 & 0.681 & 13.757 & $<0.001$ \\
\hline & & & & \\
\hline
\end{tabular}

Table 6. Validity and Reliability Results.

\begin{tabular}{lcc}
\hline Construct & Composite Reliability (CR) & Average Variance Extracted (AVE) \\
\hline PUE & 0.839 & 0.573 \\
\hline PSE & 0.924 & 0.803 \\
\hline PEE & 0.896 & 0.683 \\
\hline BIE & 0.891 & 0.730 \\
\hline
\end{tabular}

As per the validity and reliability analysis (Table 6), the Composite Reliability (CR) of each latent construct is more than the acceptable limit of 0.70 . It reveals that there is a strong internal consistency in the scale items. On the other hand, the Average Variance Extracted (AVE) of each latent construct exceeds the threshold limit of 0.5 . It affirms that the above discussed CFA measurement model has strong convergent validity. This part of the questionnaire aims at fetching the information regarding students' perception for e-learning through Likert scale ("Strongly Disagree" to "Strongly Agree"). The broad headings contain usefulness, self-efficacy, ease of use and behavioural intention of using of e-learning platforms. The study looks at the perception of students as it is indispensable for designing, development and to deliver course teaching online which is based on learners' perception and need. "Strongly Agree" \& "Agree" are clubbed together to form one positive response i.e., Agree and "Strongly Disagree" and "Disagree" were also combined to get one response from the sample respondents which is "Disagree". "Neutral" was left as it is. The results are shown in Table 7.

The respondents have indicated their perceptions and their own capability to make use of e-learning platform. The responses so received show that $56.5 \%$ of the respondents have confidence of using e-learning platform. Additionally, $60.3 \%$ of the respondents have 
shown confidence about operating the functions of e-learning and $61.4 \%$ indicate their confidence for learning the online study content. Thus, most of the students are found to be comfortable and confident with the use of learning systems. These results are aligned with the finding [41] that shows that majority of the students who have positive perception about e-learning are the ones who are frequent e-learners. The study intends to examine the behavioural intention of e-learners with regard to using e-learning tools. The findings listed in Table 7 shows that $79.9 \%$ of respondent students are using e-learning as an aid of their learning; 85.3\% of respondent students are using e-learning for updating their subject knowledge and keep track of amendments if any; $86.9 \%$ of respondent students are using e-learning as a free-learning tool. The major findings of the study illustrates that behavioural intention of students regarding e-learning is encouraging and positive. It is expected that students' perception would impact their satisfaction positively through interactive e-learning.

The researchers sought to determine the usefulness of the e-learning resources. It was found that $58.7 \%$ of the respondents believed that studying through e-learning mode provides the flexibility to study at the time convenient to the learner, whereas $22.3 \%$ respondents preferred to remain neutral. Whereas, $73.4 \%$ of the respondents believed that e-learning enables students to pursue their studies irrespective of geographical disparities and facilitates exams and submission of assignments electronically. In the last variable, $68 \%$ of the respondents agreed that the effectiveness of communication indeed is possible between instructor and learner without face-to-face interaction, while $20 \%$ remained neutral.

As far as "Perceived Ease of Use of E-learning" is concerned, the study finds that $52.2 \%$ of the students believe that e-learning platforms are user friendly, while $32.1 \%$ of the sample respondents were neutral. $68 \%$ of the students have observed that through e-learning system we can easily access the necessary information, while $19 \%$ of the sample respondents were neutral and 13\% of the students have opined that they are unable to explore the necessary information through e-learning system. 50\% of the sample respondents believed that web-based learning system simplifies the-learning process for the students, while $25.5 \%$ were neutral and $24.5 \%$ of the respondents were not in favor of this. In the last variable, $42.3 \%$ of the students have observed that the set-up of the e-learning service is compatible with the way they learn. However, $33.2 \%$ of the students were undecided and $24.5 \%$ of the sample respondents were disagreed with this feature of e-learning system. 
Table 7. Students' Perceptions of E-learning $(N=184)$.

\begin{tabular}{|c|c|c|c|c|c|c|c|c|}
\hline Code & Variables & $\mathrm{SD}(\mathbf{1})$ & $\mathrm{D}(2)$ & Total $(1+2)$ & $\mathbf{N}(3)$ & $\mathbf{A}(4)$ & SA(5) & Total $(4+5)$ \\
\hline \multicolumn{9}{|c|}{ I. Perceived Usefulness of E-learning } \\
\hline PUE1 & $\begin{array}{l}\text { Studying through e-learning mode provides } \\
\text { the flexibility to the study at the time convenient to the learner. }\end{array}$ & $6 \%$ & $13 \%$ & $19 \%$ & $22.3 \%$ & $38.6 \%$ & $20.1 \%$ & $58.7 \%$ \\
\hline PUE2 & E-learning can enable people to study irrespective of where they are located in the world. & $5.4 \%$ & $7.6 \%$ & $13 \%$ & $13.6 \%$ & $35.9 \%$ & $37.5 \%$ & $73.4 \%$ \\
\hline PUE3 & There are technologies available to enable one to take tests and submit assignments electronically. & $3.3 \%$ & $6.5 \%$ & $9.8 \%$ & $16.8 \%$ & $45.7 \%$ & $27.7 \%$ & $73.4 \%$ \\
\hline PUE4 & $\begin{array}{l}\text { There are electronic tools available to enable interactive communication between } \\
\text { instructor and student without meeting face-to-face. }\end{array}$ & $4.9 \%$ & $7.1 \%$ & $12 \%$ & $20 \%$ & $45.7 \%$ & $22.3 \%$ & $68 \%$ \\
\hline \multicolumn{9}{|c|}{$\begin{array}{ll}\text { II. Perceived Self-Efficacy of Using E-learning } \\
\end{array}$} \\
\hline PSE5 & I feel confident while using e-learning system. & $6.5 \%$ & $12.5 \%$ & $19 \%$ & $24.5 \%$ & $36.4 \%$ & $20.1 \%$ & $56.5 \%$ \\
\hline PSE6 & I feel confident while operating e-learning functions. & $5.4 \%$ & $12 \%$ & $17.4 \%$ & $22.3 \%$ & $39.7 \%$ & $20.6 \%$ & $60.3 \%$ \\
\hline PSE7 & I feel confident while using online-learning content. & $6.5 \%$ & $7.6 \%$ & $14.1 \%$ & $24.5 \%$ & $41.8 \%$ & $19.6 \%$ & $61.4 \%$ \\
\hline \multicolumn{9}{|c|}{ III. Perceived Ease of Use of E-learning } \\
\hline PEE8 & I believe e-learning platforms are user friendly. & $4.3 \%$ & $11.4 \%$ & $15.7 \%$ & $32.1 \%$ & $32.1 \%$ & $20.1 \%$ & $52.2 \%$ \\
\hline PEE9 & It would be easy for me to find necessary information when using an e-learning platform. & $4.8 \%$ & $8.2 \%$ & $13 \%$ & $19 \%$ & $44.6 \%$ & $23.4 \%$ & $68 \%$ \\
\hline PEE10 & I believe that using e-learning service can simplify the-learning process. & $7.1 \%$ & $17.4 \%$ & $24.5 \%$ & $25.5 \%$ & $32.6 \%$ & $17.4 \%$ & $50 \%$ \\
\hline \multicolumn{9}{|c|}{ IV. Behavioural Intention of Using E-learning } \\
\hline BIE12 & I intend to use e-learning to assist my learning. & $7.1 \%$ & $13 \%$ & $20.1 \%$ & $28.8 \%$ & $35.3 \%$ & $15.8 \%$ & $79.9 \%$ \\
\hline BIE13 & I intend to use e-learning to get updated my subject knowledge with the latest amendments. & $6.5 \%$ & $8.2 \%$ & $14.7 \%$ & $25 \%$ & $36.4 \%$ & $23.9 \%$ & $85.3 \%$ \\
\hline BIE14 & I intend to use e-learning as an autonomous (free) learning tool. & $7.1 \%$ & $6 \%$ & $13.1 \%$ & $21.7 \%$ & $39.7 \%$ & $25.5 \%$ & $86.9 \%$ \\
\hline
\end{tabular}




\section{Conclusions}

The present study analyses the perception of university students towards e-learning during the ongoing COVID-19 pandemic. The study reveals the preferences of students for e-learning as it provides them much freedom to connect with their teachers, fellow students and engage with their study materials at the comfort and flexibility of space and time. The easy access of study resources is found to be one of the major reasons for the students to opt for e-learning. The study indicates that e-learning technology enables easy information access leading to positive attitude formation of students towards it. This finding is based on usefulness, self-efficacy, ease of use, and the behaviour of students as regards e-learning. The study affirms the usefulness of e-learning such as ease of study from any geographical location which is not possible in case of conventional face to face-learning. Furthermore, the study illustrates the similar experience of being educated as done through the physical classroom teaching as students perceive e-learning as analogous to face to face-learning.

However, unlike past research conducted by Abbasi et al. [42], this research study indicated that in the recent past, e-learning has gained immense popularity in India as students are found to be inclined towards online learning tools to interact with each other and the educators as well. Furthermore, in the absence of face-to-face interaction, digital technology has also been well accepted by the students for the purpose of learning. Therefore, necessary measures should be adopted for improving the quality of E-learning to help with better learning of students during the phase of Covid-19 pandemic.

Author Contributions: Conceptualization, M.A.K. and V.; Resources, M.K.N., M.A.K. and M.T.; Investigation, M.A.K. and M.K.; methodology, M.A.K., V. and M.K.N.; writing-original draft preparation, V. and M.K.; writing-review and editing, M.T., V., M.K.N. and M.K.; supervision, M.A.K. and M.K.N.; project administration, M.A.K. and V. All authors have read and agreed to the published version of the manuscript.

Funding: This research received no external funding.

Conflicts of Interest: The authors declare no conflict of interest.

\section{References}

1. Zayabalaradjane, Z. COVID-19: Strategies for Online Engagement of Remote Learners. F1000Research 2020, 9, 246.

2. Muzaffar, A.W.; Tahir, M.; Anwar, M.W.; Chaudry, Q.; Mir, S.R.; Rasheed, Y. A Systematic Review of Online Exams Solutions in E-learning: Techniques, Tools, and Global Adoption. arXiv 2020, arXiv:2010.07086.

3. Henderson, D.; Woodcock, H.; Mehta, J.; Khan, N.; Shivji, V.; Richardson, C.; Aya, H.; Ziser, S.; Pollara, G.; Burns, A. Keep calm and carry on learning: using Microsoft teams to deliver a medical education programme during the COVID-19 pandemic. Future Healthc. J. 2020, 7, e67. [CrossRef] [PubMed]

4. Sá, M.J.; Serpa, S. The COVID-19 Pandemic as an Opportunity to Foster the Sustainable Development of Teaching in Higher Education. Sustainability 2020, 12, 8525. [CrossRef]

5. Mahajan, M.V. A study of studentsâ $€^{\mathrm{TM}}$ perception about e-learning. Indian J. Clin. Anat. Physiol. 2018, 5. [CrossRef]

6. Nassoura, A.B. Measuring Students' Perceptions Of Online Learning In Higher Education. Int. J. Sci. Technol. Res. 2020. 9, 1965-1970.

7. Bali, S.; Liu, M. Students' perceptions toward online learning and face-to-face learning courses. J. Phys. Conf. Ser. 2018, 1108, 012094. [CrossRef]

8. Armstrong, D. Students' perceptions of online learning and instructional tools: A qualitative study of undergraduate students use of online tools. Turk. Online J. Educ. Technol. 2011, 10, 222-226.

9. Biswas, B.; Roy, S.K.; Roy, F. Students Perception of Mobile Learning during COVID-19 in Bangladesh: University Student Perspective. Aquademia2020, 4, ep20023. [CrossRef]

10. Shrestha, E.; Mehta, R.S.; Mandal, G.; Chaudhary, K.; Pradhan, N. Perception of the learning environment among the students in a nursing college in Eastern Nepal. BMC Med. Educ. 2019, 19, 382. [CrossRef]

11. Salloum, S.A.; Al-Emran, M.; Shaalan, K.; Tarhini, A. Factors affecting the E-learning acceptance: A case study from UAE. Educ. Inf. Technol. 2019, 24, 509-530. [CrossRef]

12. Pérez-Pérez, M.; Serrano-Bedia, A.M.; García-Piqueres, G. An analysis of factors affecting students’ perceptions of learning outcomes with Moodle. J. Furth. High. Educ. 2020, 44, 1114-1129. [CrossRef]

13. Al Kurdi, B.; Alshurideh, M.; Salloum, S.A. Investigating a theoretical framework for e-learning technology acceptance. Int. J. Electr. Comput. Eng. 2020, 10, 6484-6496. 
14. Kennedy, G.; Krause, K.L.; Gray, K.; Judd, T.; Bennett, S.J.; Maton, K.A.; Dalgarno, B.; Bishop, A. Questioning the net generation: A collaborative project in Australian higher education. In Proceedings of the Annual Conference of the Australasian Society for Computers in Learning in Tertiary Education, Sydney, Australia, 3-6 December 2006; Sydney University Press: Sydney, Australia, 2006; pp. 413-417.

15. Kennedy, G.E.; Judd, T.S.; Churchward, A.; Gray, K.; Krause, K.L. First year students' experiences with technology: Are they really digital natives? Australas. J. Educ. Technol. 2008, 24. [CrossRef]

16. Kvavik, R.B. Convenience, communications, and control: How students use technology. Educ. Net Gener. 2005, 1, 7-1.

17. Salaway, G.; Caruso, J.B.; Nelson, M.R. The ECAR Study of Undergraduate Students and Information Technology, 2008; EDUCAUSE Center for Applied Research: Minneapolis, MI, USA, 2007; Volume 6.

18. Green, H.; Hannon, C. Their Space: Education for a Digital Generation; DEMOS: New York, NY, USA, 2007.

19. Rogers, E.M.; Singhal, A.; Quinlan, M.M. Diffusion of Innovations 1. In An Integrated Approach to Communication Theory and Research; Routledge: New York, NY, USA, 2019; pp. 415-434.

20. Dearing, J.W.; Cox, J.G. Diffusion of innovations theory, principles, and practice. Health Aff. 2018, 37, 183-190. [CrossRef]

21. Mlekus, L.; Bentler, D.; Paruzel, A.; Kato-Beiderwieden, A.L.; Maier, G.W. How to raise technology acceptance: user experience characteristics as technology-inherent determinants. Gr. Interaktion. Organ. Z. Angew. Organ. 2020, 51, 273-283. [CrossRef]

22. Gray, J.A.; DiLoreto, M. The effects of student engagement, student satisfaction, and perceived learning in online learning environments. Int. J. Educ. Leadersh. Prep. 2016, 11, n1.

23. Zhu, X. Facilitating Effective Online Discourse: Investigating Factors Influencing Students' Cognitive Presence in Online Learning. Master's Thesis, University of Connecticut Graduate School, Storrs, CT, USA, 2018.

24. Martin, F.; Bolliger, D.U. Engagement matters: Student perceptions on the importance of engagement strategies in the online learning environment. Online Learn. 2018, 22, 205-222. [CrossRef]

25. Chandra, Y. Online education during COVID-19: Perception of academic stress and emotional intelligence coping strategies among college students. Asian Educ. Dev. Stud. 2020. [CrossRef]

26. Alhazzani, N. MOOC's impact on higher education. Soc. Sci. Humanit. Open 2020, 2, 100030. [CrossRef]

27. Cervi, L.; Pérez Tornero, J.M.; Tejedor, S. The challenge of teaching mobile journalism through MOOCs: A case study. Sustainability 2020, 12, 5307. [CrossRef]

28. Kumar, P.; Kumar, N. A study of learner's satisfaction from MOOCs through a mediation model. Procedia Comput. Sci. 2020, 173, 354-363. [CrossRef]

29. Hair, J.F.; Black, W.C.; Babin, B.J.; Anderson, R.E.; Tatham, R.L. Multivariate Data Snalysis, (Vol. 6); Pearson Prentice Hall: Upper Saddle River, NJ, USA, 2006.

30. Sekaran, U.; Bougie, R. Research Methods for Business: A Skill Building Approach; John Wiley \& Sons: New York, NY, USA, 2016.

31. Taber, K.S. The use of Cronbach's alpha when developing and reporting research instruments in science education. Res. Sci. Educ. 2018, 48, 1273-1296. [CrossRef]

32. Juárez Santiago, B.; Olivares Ramírez, J.M.; Rodríguez-Reséndiz, J.; Dector, A.; García García, R.; González-Durán, J.E.E.; Ferriol Sánchez, F. Learning Management System-Based Evaluation to Determine Academic Efficiency Performance. Sustainability 2020, 12, 4256. [CrossRef]

33. Oguguo, B.C.; Nannim, F.A.; Agah, J.J.; Ugwuanyi, C.S.; Ene, C.U.; Nzeadibe, A.C. Effect of learning management system on Student's performance in educational measurement and evaluation. Educ. Inf. Technol. 2020. [CrossRef]

34. Bralić, A.; Divjak, B. Integrating MOOCs in traditionally taught courses: achieving learning outcomes with blended learning. Int. J. Educ. Technol. High. Educ. 2018, 15, 2. [CrossRef]

35. Almaiah, M.A.; Al-Khasawneh, A.; Althunibat, A. Exploring the critical challenges and factors influencing the E-learning system usage during COVID-19 pandemic. Educ. Inf. Technol. 2020, 25, 5261-5280. [CrossRef]

36. Eze, S.C.; Chinedu-Eze, V.C.; Okike, C.K.; Bello, A.O. Factors influencing the use of e-learning facilities by students in a private Higher Education Institution (HEI) in a developing economy. Humanit. Soc. Sci. Commun. 2020, 7, 1-15. [CrossRef]

37. Palvia, S.; Aeron, P.; Gupta, P.; Mahapatra, D.; Parida, R.; Rosner, R.; Sindhi, S. Online education: Worldwide status, challenges, trends, and implications. J. Glob. Inf. Technol. Manag. 2018, 21, 233-241. [CrossRef]

38. Valverde-Berrocoso, J.; Garrido-Arroyo, M.d.C.; Burgos-Videla, C.; Morales-Cevallos, M.B. Trends in educational research about e-learning: A systematic literature review (2009-2018). Sustainability 2020, 12, 5153. [CrossRef]

39. Landrum, B.; Bannister, J.; Garza, G.; Rhame, S. A class of one: Students' satisfaction with online learning. J. Educ. Bus. 2020. [CrossRef]

40. Abbott, A.A. A confirmatory factor analysis of the Professional Opinion Scale: A values assessment instrument. Res. Soc. Work. Pract. 2003, 13, 641-666. [CrossRef]

41. Ituma, A. An evaluation of students' perceptions and engagement with e-learning components in a campus based university. Act. Learn. High. Educ. 2011, 12, 57-68. [CrossRef]

42. Abbasi, S.; Ayoob, T.; Malik, A.; Memon, S.I. Perceptions of students regarding E-learning during Covid-19 at a private medical college. Pak. J. Med. Sci. 2020, 36, S57-S61. [CrossRef] 